\title{
Towards A New Approach of Local Development under Crisis \\ Conditions: Empowering the Local Business Ecosystems in Greece, by Adopting a New Local Development Policy
}

\author{
Charalampos Vlados \\ Department of Economics \\ Democritus University of Thrace
}

\author{
Nikolaos Deniozos \\ Department of Turkish Studies and Modern Asian Studies \\ National and Kapodistrian University of Greece \\ Demosthenes Chatzinikolaou (Correspondence) \\ Department of Law \\ Democritus University of Thrace \\ E-mail: dimos.chatzinikolaou@gmail.com
}

Received: October 6, 2017 Accepted: November 8, 2017 Published: December 2, 2017

doi:10.5296/ijrd.v5i1.11955 URL: http://dx.doi.org/10.5296/ijrd.v5i1.11955

\begin{abstract}
The competitiveness of the Greek economy evolves, both in the present crisis and later on, according to the dynamic micro-level environment and its transformations. This evolution depends on the SME's abilities to claim a significant role in the new, competitive global environment, which is characterized by a continuous reshaping process. Respectively, the goal of achieving development in the local scale is of vital importance. This paper attempts to approach and highlight a new framework, by proposing a new business ecosystems approach and policy, focusing on the implementation of a method for strengthening the SME's physiology. This method proposes the construction of systematic knowledge and innovation mechanisms, on a local scale; the Local Development and Innovation Institutes (LDI's). Subsequently, we analyze the regional data in Greece in order to highlight the most affected
\end{abstract}


by the crisis region and to experimentally establish the Local Development Institutes.

Keywords: Local Development \& Innovation Institutes; LDIs'; Business Ecosystems; SMEs; Greece

\section{Introduction}

Over the recent years, there has been an extended economic crisis which has a hit significantly the small and medium-sized enterprises (SME) in Greece. It has created an underlying negative environment for all the new and existing companies due to a liquidity shortage, high taxation, a decrease in consumption demand, high operating costs, an intensified competition of low-priced imported goods and of larger companies and, mostly, because of the volatile and uncertain political and economic macro-conditions. This crisis in Greece goes way beyond the analytical perspective of insufficient demand. It is in fact necessary to help modernize the supply mechanisms of the local ecosystems in order for them to build efficient competitive advantages.

Based on the 2015 research outcome of the "IOBE" (Greek Foundation for Economic and

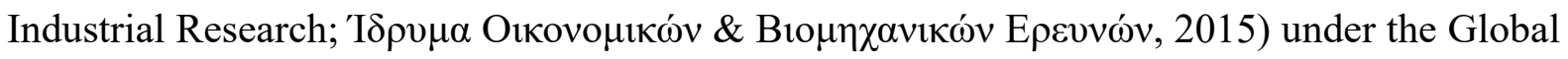
Entrepreneurship Monitor program (GEM), the business environment on the ground remains one of the least innovation friendly throughout the European Union. The process of conducting entrepreneurial activity is held back by the absence of a broader national policy -a framework that would favor entrepreneurship. Significant entrepreneurial obstacles apart from funding, consist of high market entry barriers as well as the dominant - rather ambiguous - business culture. As far as the structural nature of the competitiveness problem (B $\lambda \alpha ́ \delta$ os, 2016) concerned, the Greek SME's and their domestic business environment are now facing intertemporal weaknesses and a lack of competitive advantages (Vlados, 1996). Therefore, the successful adaptation of the locally established SME's will be the major factor in defining the international competitiveness of the Greek economy (Vlados, 2005; Vlados, 2012).

\section{A Brief Overview of Entrepreneurship in Greece}
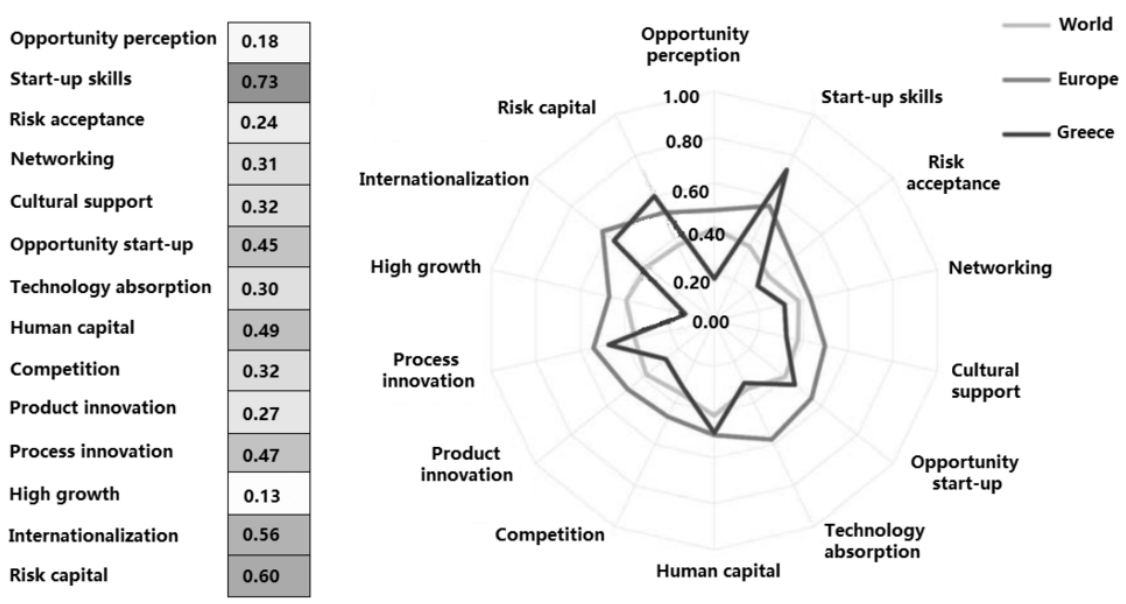

Figure 1. Pillars of Performance for the entrepreneurship in Greece (Ács et al., 2017) 
From the above Pillars of Performance graph (Figure 1) relating to the entrepreneurship in Greece, "Start-up skills" is the strongest area (0.73), while "High growth" constitutes the weakest (0.13). Furthermore, Global Entrepreneurial Index, GEI ranking [Ács et al., (2017), p. 56], of the European countries, shows that Greece is close to the bottom, in the $49^{\text {th }}$ position (GEI, 34.6), while the European index is 46.3. Regarding the sub-indices comparison, Entrepreneurial Attitudes sub-index (ATT), Entrepreneurial Abilities sub-index (ABT) and Entrepreneurial Aspirations sub-index (ASP), Greece performs 32.1, 35.8 and 36 , while the European totals are $44,47.3$ and 47.6 respectively.

At the same time, a research conducted recently by the Ministry of Economy and Development in order to "Map the business needs of Greek Startups" (Гєvıкท́ Г $\propto \mu \mu \alpha \tau \varepsilon i ́ \alpha$ Bıo $\left.\chi_{\chi \alpha} \alpha v^{\alpha} \alpha \varsigma, 2016\right)$ identified two major trends; their main source of financing is own capital (amazingly, 83.5\%) while $60.2 \%$ of them focus on the foreign market (in contrast, only $47.7 \%$ has an exclusive domestic orientation). A further analysis of the data shows that $23.5 \%$ is financed through family and relatives, 9.4\% utilizes grants and awards, $7.1 \%$ benefits from subsidies and only $4.7 \%$ borrows from banking and financial institutions.

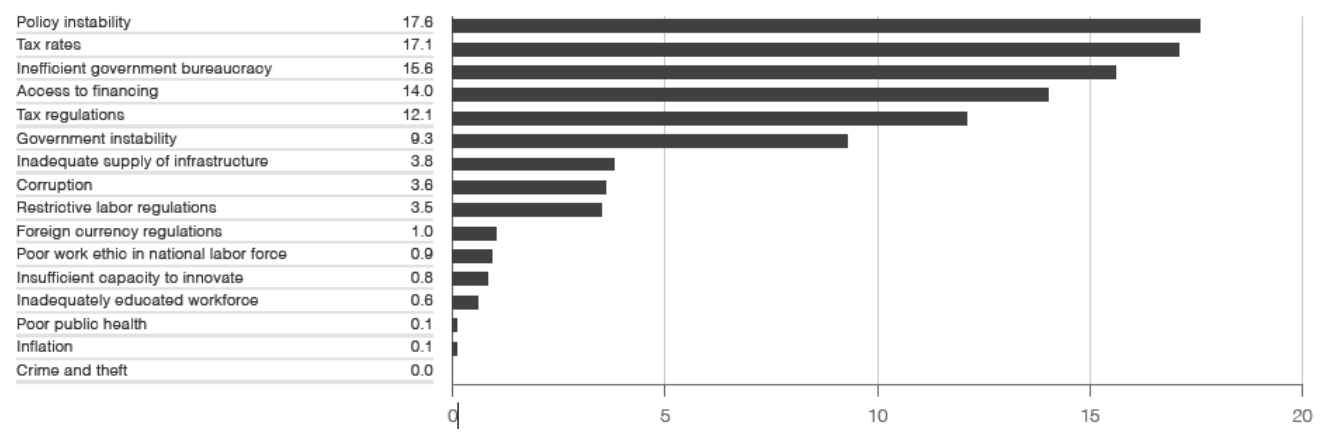

Figure 2. Most Problematic factors for conducting business in Greece (Schwab et al., 2016)

Finally, the above chart (Figure 2) demonstrates the order of factors that impede entrepreneurship; the instability of policy measures is the number one problem to deal with, followed by high taxes, bureaucracy, access to financing and tax regulations. Other significant deterrents are the governmental instability, the inadequate infrastructure as well as restrictive labor regulations etc.

\section{Business Ecosystems and Local Development}

The biological term "ecosystem" was first coined by the British botanist, Arthur Tansley (Tansley, 1935). He supported the idea that the basic units of nature can be understood as ecosystems; physical spaces with resources, such as oxygen and other gases, soil, minerals, and water; and lots of species, from trees, mammals, reptiles, insects, bacteria, that are sharing resources, creating resources from one another, competing for resources, co-evolving and constantly adapting.

Nowadays —and after the initial contribution by James Moore (Moore, 1993) - the prevailing concept of "Business Ecosystems" has paved the way for further study in the ecology of businesses. The business ecosystem approach (Table 1) is, primarily, a way to think in terms of strategy and of the effort needed to accelerate progress. The field of study 
and scope of business ecosystems is the behaviour and development of a population of businesses - living organisms - that co-evolve and act in very complex ways (Peltoniemi, 2005).

Table 1. A brief overview of the business ecosystem definitions

\begin{tabular}{lll}
\hline No. & Author \& Year & How they describe the business ecosystem \\
\hline 1. (Moore, 1993) & Like its biological counterpart, gradually moves from a random \\
& collection of elements to a more structured community. \\
2. (Moore, 1996) & An economic community supported by a foundation of interacting \\
& organisations and individuals - the organisms of the business world. \\
& This economic community produces goods and services of value to \\
& customers, who are themselves members of the ecosystem. The \\
& member organisations also include suppliers, lead producers, \\
& competitors, and other stakeholders. Over time, they co-evolve their \\
& capabilities and roles, and tend to align themselves with the directions \\
& set by one or more central companies. Those companies holding \\
& leadership roles may change over time, but the function of ecosystem \\
& leader is valued by the community because it enables members to move \\
& toward shared visions to align their investments and to find mutually \\
& supportive roles.
\end{tabular}

3. (Iansiti and Levien, A business ecosystem is a business network, which is formed by large 2004) and loosely connected networks of entities that interact with each other in complex ways, while the health and performance of a firm is dependent on the health and performance of the whole.

4. (Peltoniemi and A dynamic structure which consists of an interconnected population of Vuori, 2004) organisations. These organisations can be small firms, large corporations, universities, research centers, public sector organisations, and other parties which influence the system.

5. (Fragidis et al., Business ecosystems concentrate large populations of different kinds of 2007) business entities. They transcend industry and supply chain boundaries and assemble a variety of organisations that can complement each other and synergistically produce composite products. Interdependence and symbiotic relationships are inherent attributes in business ecosystems; as a result, the participants counter a mutual fate and co-evolve with each other. But in parallel, members compete with each other for the acquirement of resources and the attraction of customers.

6. (Marín et al., 2007) To flourish in such environments, businesses must continually adapt and evolve. This requires that a business engage in an ongoing dialogue with its environment and with others with which it shares this environment.

7. (Desai et al., 2007) Dynamic, customizable groups of services provided and used by membership-based social or business networks of varying scale and lifetime. 
8. (Anggraeni et al., The business ecosystem perspective offers a new way to obtain a 2007) holistic view of the business network and the relationships and mechanisms that are shaping it, while including the roles and strategies of the individual actors that are a part of these networks.

9. (Chang and Uden, A business ecosystem is a network of buyers, suppliers and makers of 2008) related products or services and their socio-economic environment that includes institutional and regulatory framework.

$10 \quad(\mathrm{Li}, 2009)$ A business ecosystem provides a new perspective for repositioning a company's strategy in order to aggressively further its own interests and to promote its overall ecosystem health.

11. (Williamson and A network of organisations and individuals that co-evolve their De Meyer, 2012) capabilities and roles and align their investments so as to create additional value and/or improve efficiency.

12. (Rong and Shi, A business ecosystem is a community consisting of different levels of 2015) interdependent organisations which generates co-evolution between partners and their business environment.

Adapted from Rong and Shi (2015).

Every business ecosystem (Figure 3, below) springs out of the original swirl of capital and knowledge, customer interest and markets, new value and talent generated by a new innovation, just as successful species spring from the natural resources of sunlight, water, and soil nutrients. The goal is to get a lot of people to bring their creativity together and accomplish something more important than they can do on their own. In general a business ecosystem tries to be wildly inclusive, and in its extreme tries to harness the productivity of a swarm. (Moore, 2014)

There are four distinct stages of a business ecosystem development: birth, expansion, leadership, and self-renewal -or, if not self-renewal, death (Table 2). In reality, of course, the evolutionary stages blur, and the managerial challenges of one stage often crop up in another. What remains the same from business to business is the process of co-evolution; the complex interplay between competitive and cooperative business strategies (Moore, 1993, p. 76).

Table 2. The evolutionary stages of a business ecosystem

\begin{tabular}{lll}
\hline & Cooperative Challenges & Competitive Challenges \\
\hline $\begin{array}{l}\text { Phase 1: } \\
\text { Birth }\end{array}$ & $\begin{array}{l}\text { Work with customers and suppliers to } \\
\text { define the new value proposition around a } \\
\text { seed innovation. }\end{array}$ & $\begin{array}{l}\text { Protect your ideas from others who might } \\
\text { be working toward defining similar offers. } \\
\text { Tie up critical lead customers, key } \\
\text { suppliers, and important channels. }\end{array}$ \\
$\begin{array}{l}\text { Phase } \\
\text { Expansion }\end{array}$ & $\begin{array}{l}\text { Bring the new offer to a large market by } \\
\text { working with suppliers and partners to } \\
\text { scale up supply and to achieve maximum } \\
\text { market coverage. }\end{array}$ & $\begin{array}{l}\text { Defeat alternative implementations of } \\
\text { is the market standard in its class through } \\
\text { dominating key market segments. }\end{array}$ \\
$\begin{array}{l}\text { Phase } \\
\text { Leadership }\end{array}$ & $\begin{array}{l}\text { Provide a compelling vision for the future } \\
\text { that encourages suppliers and customers }\end{array}$ & $\begin{array}{l}\text { Maintain strong bargaining power in } \\
\text { relation to other players in the ecosystem, }\end{array}$ \\
\hline
\end{tabular}


to work together to continue improving including key customers and valued the complete offer.

suppliers.

Phase 4: Work with innovators to bring new ideas Maintain high barriers in entry to prevent

Self-Renewal to the existing ecosystem. innovators from building alternative ecosystems. Maintain high customer switching costs in order to buy time to incorporate new ideas into your own products and services.

Reproduced from Moore (Moore, 1993, p. 77).

During Stage 1 of a business ecosystem, entrepreneurs focus on defining what customers want, that is, the value of a proposed new product or service and the best form for delivering it.

In Stage 2, business ecosystems expand to conquer broad new territories. Just as grasses and weeds rapidly cover the bare, scorched ground left after a forest fire, some business expansions meet little resistance. But in other cases, rival ecosystems may be closely matched and choose to attack the same territory.

Similarly, in business ecosystems, two conditions contribute to the onset of leadership struggles that are the hallmark of Stage 3. First, the ecosystem must have strong enough growth and profitability to be considered worth fighting over. Second, the structure of the value-adding components and processes that are central to the business ecosystem must become reasonably stable.

This stability allows suppliers to target particular elements of value and to compete in contributing them. It encourages members of the ecosystem to consider expanding by taking over activities from those closest to them in the value chain. Most of all, it diminishes the dependence of the whole ecosystem on the original leader. It's in Stage 3 that companies become preoccupied with standards, interfaces, "the modular organisation," and customer supplier relations.

Stage 4 of a business ecosystem occurs when mature business communities are threatened by rising new ecosystems and innovations. Alternatively, a community might undergo the equivalent of an earthquake; sudden rise of new environmental conditions that include changes in government regulations, customer buying patterns, or macroeconomic conditions (Moore, 1993, pp. 76-81). 


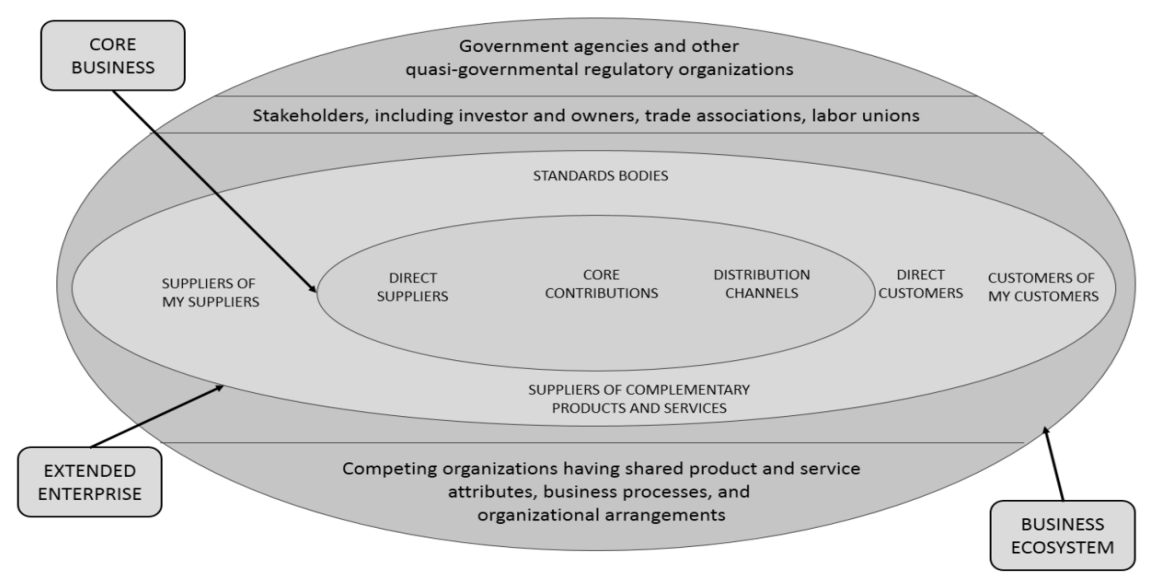

Figure 3. A typical business ecosystem

Source: Moore, 1996.

Iansity and Lenvien (Iansiti and Levien, 2004), point out that despite the immense interdependence between businesses, a company ought to determine its place in the business ecosystem. Thus, it can follow three main strategic roles: a Keystone, a Dominator, or a Niche Player. In order to develop a strategy, the first and foremost action a manager has to take is to measure the health of the underlying business ecosystem - how productive, robust, and niche creative is. The power to do so depends on the role - current and potentialwithin the network (the three main roles).

The company's choice of ecosystem strategy is governed primarily by what kind of a company it is or aims to be. This choice can also be affected by the business context in which it operates - the general level of turbulence and complexity of its relationships with others in the ecosystem.

The strategic scenarios, therefore, follow some specific paths: a) Niche strategy: if the business faces rapid and constant change and - by leveraging the assets of other firms - can focus on a narrowly and clearly defined business segment; b) Keystone strategy: if it is at the center of a complex network of asset-sharing relationships and operates in a turbulent environment; c) Physical Dominator strategy: if it relies on a complex network of external assets but operates in a mature industry; d) Value Dominator strategy: if it chooses to extract maximum value from a network of assets that doesn't control and, finally, e) if it is a commodity business that operates in a stable and mature environment and operates relatively independently of other organisations, the Ecosystem strategy is irrelevant (although that may change soon). [Iansiti and Levien, (2004), pp. 7-8]

The implications from the business ecosystem thinking are, more or less, the ripple effects throughout the entire network of organisations. One might no longer design or conceive of a product in isolation. This process, in addition, creates opportunities for innovation and product development and therefore a healthy ecosystem - new products that can leverage the capabilities provided by existing products. 


\section{Macrothink}

\section{Institutes for Local Development and Innovation}

The vast majority of businesses internationally - as well as in Greece and the rest of Europe - are small and medium-sized enterprises (Eurostat, 2011). There is, indeed, a clear distinction between big and small businesses. Nevertheless, some SME's are significantly better than others; behind similar quantities there are massive qualitative variations and the comparable sizes are, sometimes, inefficient in the process of defining different qualities and "kinds" (B $\lambda \alpha ́ \delta o s, 2016)$.

Therefore, a sustainable way out of the persistent Greek economic crisis lies at the inclusive policies that could help the development of the SME's environment - the majority, that is, of the economic actors in Greece. One such policy is the proposed Local Development \& Innovation Institutions (LDI's) (Vlados, 2017). The Local Development Institutes are specific mechanisms to promote, coordinate, and spread information and business know-how. As for their core value, they are capable to create and disseminate socioeconomic interest by harnessing the innovation process, on a local scale, and by helping businesses to develop their extroversion skills and physiology.

This LDI's mechanism is, basically, an effort - an intervention - to directly support the businesses that exist and grow in a specific business ecosystem on a local level. To achieve that, the LDI require sufficient resources, both tangible and intangible, adequate infrastructure - as well as specialized scientists - all of which remain uncoordinated in various state bodies and institutions. So, the idea is to re-organize and build a chain of value creation around them, locally (Figure 4).

The VALUE CHAIN of LOCAL DEVELOPMENT INSTITUTES

Six Loops

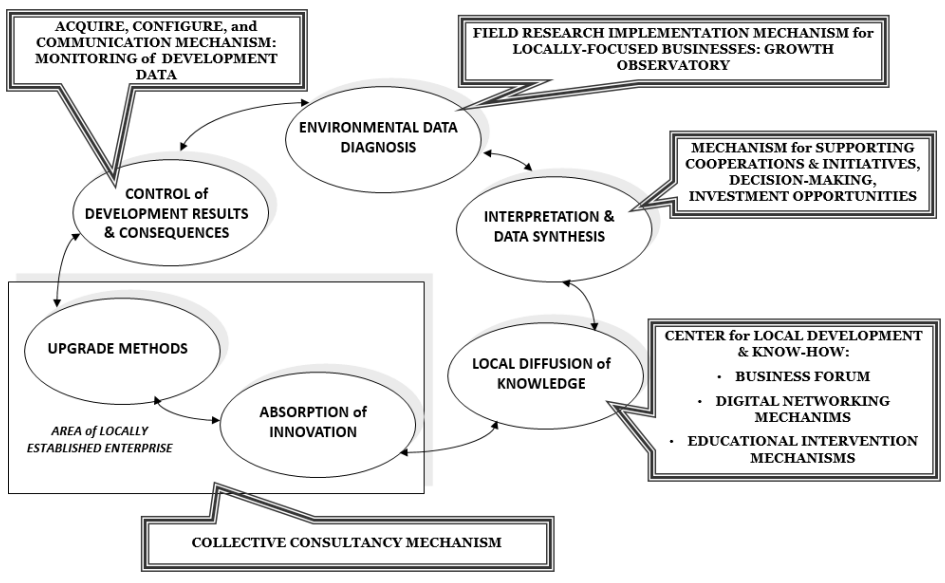

Figure 4. The six-loop value-chain of the Local Development \& Innovation Institutions 
LOCAL DEVELOPMENT INSTITUTES

Overall Management and Structure

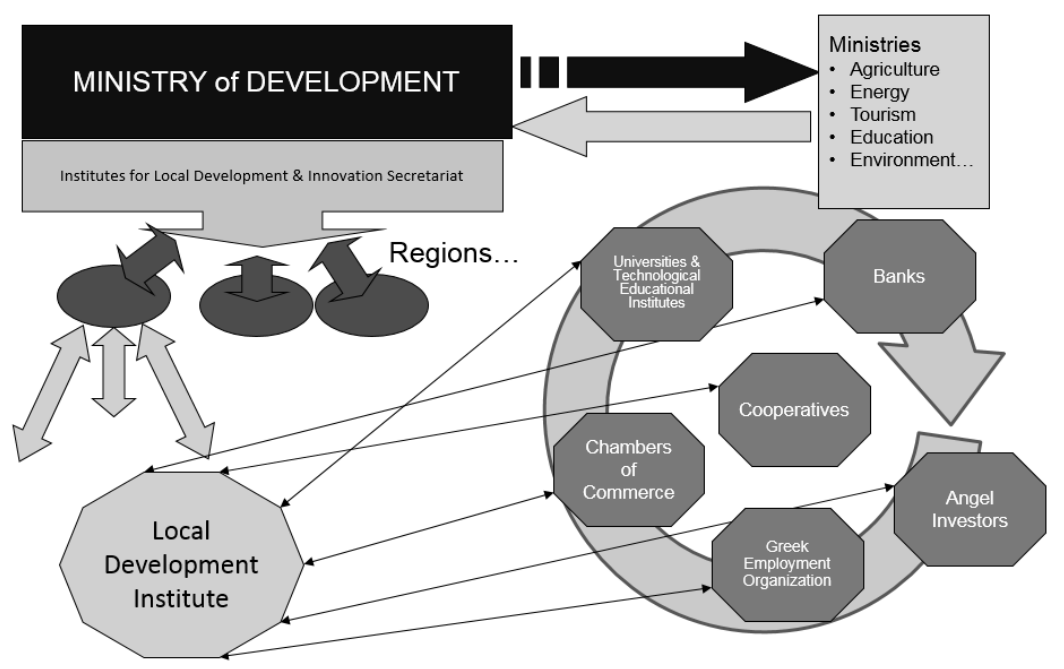

Figure 5. The structure of the Local Development \& Innovation Institutions

In other words, the LDIs serve as offices responsible for business support, development and growth, throughout the regions, prefectures and municipalities in Greece. They are, in fact, a point of contact for all the government agencies and organisations, related to innovation and to the regional productive powers (Figure 5).

That said, in order for the LDIs to succeed "on the battlefield", they need a flexible and proactive approach. An intelligent design as well as a regulation framework that will ensure the stability and the core competencies of the mechanism: Speed and reliability, synergistic approach, value-added structural measures, and the enhancement of the local business ecosystems (B $\lambda \alpha \dot{\delta} \delta o \zeta, 2006)$.

\section{Quantitative Analysis, Based on Regional Data}

The next step in this proposed method is to clarify which business ecosystem has some form of priority in establishing and implementing a pilot LDI policy. So, the target-region in our

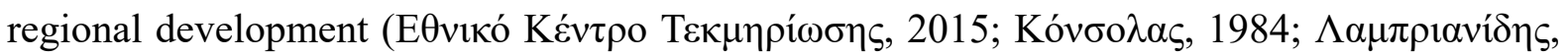

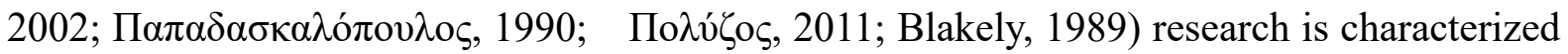
by relative losses and difficulties to adjust throughout the crisis period (from 2008 to this day).

As such, we extract the weakest out of the regions of the Greek productive system, the particular, that is, and problematic regional area that could experimentally host a Local Development \& Innovation Institute. This region, based on our search criteria, appears to be the Eastern Macedonia \& Thrace.

It is a featured border area since all its prefectures, except Kavala, are adjacent to the borders of Greece. Border areas demonstrate the extreme syndrome of "regionality". This serves to explain the economic, social, demographic and other problems which are found in some geographical entities that cannot follow the pace of development like other - more central- 


\section{Macrothink}

International Journal of Regional Development

ISSN 2373-9851 2018, Vol. 5, No. 1

regions and cities $(\mathrm{B} \lambda \alpha \dot{\alpha} \delta o \zeta, 2007)$. As a consequence, when a region is isolated and "regionalized" there are some significant costs to deal with:

A. Financing: high operating costs for businesses as well as living costs due to high distances.

B. Infrastructure: low or absent economies of scale due to fragmentation of market activities.

C. Opportunities: weak economy with diminished expectations, both for social and economic benefits.

D. Information: relatively late in remote regions coupled with higher costs to obtain specialized information.

In particular, the following analysis begins with the calculations of some basic figures of the Greek economy (Tables 3-11), as well as of the target-region, for the 2008-2014 period. Consequently, the shift-share analysis (Tables 12-21), based on the previous calculated data, will end up in which industries of the Eastern Macedonia \& Thrace there are advantages or disadvantages and, as a conclusion, with the help of the regional classification method, we take the best out of each region's industry by proposing the most adequate strategy to follow.

Table 3. GDP per capita

\begin{tabular}{|c|c|c|c|}
\hline \multicolumn{4}{|c|}{ By Region, 2008 \& 2014* (EUR, current prices) } \\
\hline & 2008 & 2014 & CHANGE \% \\
\hline GREECE & 21845 & 16336 & $-25.2 \%$ \\
\hline ATTICA & 29215 & 23377 & $-23.4 \%$ \\
\hline NORTH AEGEAN & 17647 & 12919 & $-26.8 \%$ \\
\hline SOUTH AEGEAN & 24747 & 17899 & $-27.7 \%$ \\
\hline CRETE & 19176 & 13773 & $-28.2 \%$ \\
\hline $\begin{array}{l}\text { EASTERN } \\
\text { MACEDONIA, } \\
\text { THRACE }\end{array}$ & 15568 & 11366 & $-27 \%$ \\
\hline $\begin{array}{l}\text { CENTRAL } \\
\text { MACEDONIA }\end{array}$ & 17437 & 12500 & $-28.3 \%$ \\
\hline $\begin{array}{l}\text { WESTERN } \\
\text { MACEDONIA }\end{array}$ & 16748 & 15624 & $-6.7 \%$ \\
\hline EPIRUS & 14960 & 11606 & $-22.4 \%$ \\
\hline THESSALY & 16363 & 12237 & $-25.21 \%$ \\
\hline IONIAN ISLANDS & 21759 & 14826 & $-31.8 \%$ \\
\hline WESTERN GREECE & 16393 & 12214 & $-25.5 \%$ \\
\hline CENTRAL GREECE & 19552 & 13917 & $-28.8 \%$ \\
\hline PELOPONNESE & 17224 & 13134 & $-23.8 \%$ \\
\hline $\begin{array}{ll}\text { COEFFICIENT } & \text { OF } \\
\text { VARIATION }(\mathrm{CV}) & \\
\end{array}$ & 21.5 & 45.81646 & \\
\hline
\end{tabular}

Source: Hellenic Statistical Authority (Note 1)- Calculated data. *Temporary data. Update 17/01/2017. 
Table 4. GDP per capita

\begin{tabular}{lccc}
\hline \multicolumn{3}{l}{ Eastern Macedonia and Thrace prefectures, 2008 \& $2014 *$ (EUR, current prices) } \\
& $\mathbf{2 0 0 8}$ & $\mathbf{2 0 1 4}$ & CHANGE \% \\
\hline EASTERN & & & \\
MACEDONIA, & $\mathbf{1 5 5 6 8}$ & $\mathbf{1 1 3 6 6}$ & $\mathbf{- 2 7 \%}$ \\
THRACE TOTAL & & & \\
EVROS & 15438 & 12019 & $\mathbf{- 2 2 \%}$ \\
XANTHI & 14537 & 9805 & $\mathbf{- 3 2 . 5 5 \%}$ \\
RODOPE & 15148 & 9954 & $\mathbf{- 3 4 . 3 \%}$ \\
DRAMA & 13377 & 10601 & $\mathbf{- 2 0 . 7 5 \%}$ \\
KAVALA & 18388 & 13651 & $\mathbf{- 2 5 . 8 \%}$ \\
\hline
\end{tabular}

Source: Hellenic Statistical Authority - Calculated data. *Temporary data. Update 17/01/2017.

Table 5. Gross Fixed Capital Formation

\begin{tabular}{llll}
\hline \multicolumn{2}{l}{ By region, 2008 \& 2014* (EUR, current prices) } & & \\
& $\mathbf{2 0 0 8}$ & $\mathbf{2 0 1 4}$ & CHANGE \% \\
\hline GREECE & $\mathbf{5 7 6 2 7}$ & $\mathbf{2 0 6 2 5}$ & $-\mathbf{6 4 . 2 \%}$ \\
ATTICA & 22505 & 7984 & $-64.5 \%$ \\
NORTH AEGEAN & 934 & 342 & $-63.4 \%$ \\
SOUTH AEGEAN & 2130 & 647 & $-69.6 \%$ \\
CRETE & 3695 & 1184 & $-68 \%$ \\
EASTERN & & & \\
MACEDONIA, & $\mathbf{2 7 4 6}$ & $\mathbf{9 3 8}$ & $-\mathbf{6 5 . 8 \%}$ \\
THRACE & & & \\
CENTRAL & 8064 & 3555 & $-56 \%$ \\
MACEDONIA & & & $-59 \%$ \\
WESTERN & 2248 & 918 & $-71 \%$ \\
MACEDONIA & 1725 & 500 & $-63.7 \%$ \\
EPIRUS & 3199 & 1162 & $-70.8 \%$ \\
THESSALY & 1069 & 312 & $-67.3 \%$ \\
IONIAN ISLANDS & 3010 & 983 & $-59.7 \%$ \\
WESTERN GREECE & 1349 & $-67.8 \%$ \\
CENTRAL GREECE & 3345 & 951 & \\
PELOPONNESE & 2956 &
\end{tabular}

Source: Hellenic Statistical Authority - Calculated data. *Temporary data. Update 17/01/2017. 
Table 6. Employment

\begin{tabular}{llll}
\hline By region, 2008 \& 2014* & & & \\
& $\mathbf{2 0 0 8}$ & $\mathbf{2 0 1 4}$ & CHANGE \% \\
\hline GREECE & $\mathbf{4 8 5 6 3 3 3}$ & $\mathbf{3 9 9 9 2 9 6}$ & $-\mathbf{1 7 . 6 \%}$ \\
ATTICA & 1876689 & 1527414 & $-18.6 \%$ \\
NORTH AEGEAN & 76732 & 68643 & $-10.5 \%$ \\
SOUTH AEGEAN & 150811 & 133612 & $-11.4 \%$ \\
CRETE & 283873 & 237780 & $-16.2 \%$ \\
EASTERN & & & \\
MACEDONIA, & $\mathbf{2 4 3 2 5 2}$ & $\mathbf{2 1 0 8 0 4}$ & $-\mathbf{1 3 . 3 \%}$ \\
THRACE & & & \\
CENTRAL & 802478 & 635846 & $-20.8 \%$ \\
MACEDONIA & & & $-17.1 \%$ \\
WESTERN & 108445 & 89845 & $-16.7 \%$ \\
MACEDONIA & 139872 & 116567 & $-17.1 \%$ \\
EPIRUS & 317032 & 262754 & $-15.5 \%$ \\
THESSALY & 96728 & 81725 & $-19.9 \%$ \\
IONIAN ISLANDS & 283627 & 227232 & $-16.6 \%$ \\
WESTERN GREECE & 232488 & 193936 & $-12.8 \%$ \\
CENTRAL GREECE & 244325 & 213139 & \\
PELOPONNESE & &
\end{tabular}

Source: Hellenic Statistical Authority - Calculated data. *Temporary data. Update 17/01/2017.

Table 3 above shows a sharp decline in Eastern Macedonia and Thrace's GDP per capita between 2008 and 2014(27\%). This decrease is greater compared to the $25.2 \%$ country's total whereas the region's prefectures (Table 4) show a large drop especially in Xanthi and Rodope (35.2\% and 34.3\% respectively). In turn, Table 5, shows a steep decline of investments in the region ( $65.8 \%$ for 2008-2014) while the employed persons decreased by $13.3 \%$ (Table 6). The calculated coefficient of variation -21.5 for 2008 and 45.81 for 2014 (Table 3) - indicates a markable rise of the uneven distribution of GDP per capita across the Greek regions.

Table 7. Gross value added

By industry, $2008 \& 2014 *$ (EUR, current prices, in millions)

Selected Industries: AFF: Agriculture-Forestry-Fishing,

MEG: Mining-Electricity-Gas, M: Manufacturing, C: Construction,

TTAFS: Trade-Transportation-Accommodation-Food Services,

FIA: Financial and Insurance Activities, PSTA: Professional, Scientific and Technical Activities

2008

\begin{tabular}{lllllllll} 
& AFF & MEG & M & C & TTAFS & FIA & PSTA & SUM \\
\hline EVROS & 121 & 39 & 145 & 86 & 462 & 47 & 52 & $\mathbf{9 9 3}$ \\
XANTHI & 79 & 32 & 195 & 96 & 246 & 31 & 72 & $\mathbf{7 5 1}$ \\
RODOPE & 91 & 102 & 190 & 78 & 258 & 35 & 69 & $\mathbf{8 2 3}$
\end{tabular}




\begin{tabular}{llllllllll}
\hline DRAMA & 98 & 51 & 167 & 44 & 256 & 33 & 66 & $\mathbf{7 1 5}$ \\
KAVALA & 110 & 74 & 250 & 134 & 872 & 59 & 64 & $\mathbf{1 5 6 3}$ \\
SUM & $\mathbf{4 9 9}$ & $\mathbf{2 9 8}$ & $\mathbf{9 4 7}$ & $\mathbf{4 3 9}$ & $\mathbf{2 0 9 4}$ & $\mathbf{2 0 5}$ & $\mathbf{3 2 3}$ & $\mathbf{4 8 0 5}$ \\
$\mathbf{2 0 1 4}$ & & & & & & & & & \\
EVROS & 103 & 38 & 114 & 17 & 245 & 39 & 26 & $\mathbf{5 8 1}$ \\
XANTHI & 69 & 18 & 126 & 28 & 163 & 25 & 25 & $\mathbf{4 5 3}$ \\
RODOPE & 85 & 54 & 117 & 19 & 157 & 22 & 22 & $\mathbf{4 7 5}$ \\
DRAMA & 87 & 64 & 120 & 45 & 155 & 30 & 11 & $\mathbf{5 1 3}$ \\
KAVALA & 89 & 74 & 212 & 71 & 542 & 47 & 41 & $\mathbf{1 0 7 5}$ \\
SUM & $\mathbf{4 3 3}$ & $\mathbf{2 4 8}$ & $\mathbf{6 8 9}$ & $\mathbf{1 8 0}$ & $\mathbf{1 2 6 1}$ & $\mathbf{1 6 2}$ & $\mathbf{1 2 5}$ & $\mathbf{3 0 9 8}$ \\
\hline
\end{tabular}

Source: Hellenic Statistical Authority - Calculated data. *Temporary data. Update 17/01/2017.

The above table (Table 7) indicates that, for selected industries, the Gross Added Value between 2008-2014 recorded a decline of 35.5 percent in region totals while for specific prefecture the changes were: Evros: $-39 \%$, Xanthi: $-39.7 \%$, Rodope: $-73.26 \%$, Drama: $-28.25 \%$, Kavala: $-31.22 \%$. The greatest decrease was registered in Rodope.

Table 8. Gross Value Added

\begin{tabular}{lllll}
\hline \multicolumn{5}{l}{ By region and sector, 2014* (EUR, current prices, in millions) } \\
\begin{tabular}{l} 
I= Primary, II= Secondary, III= Tertiary \\
\multicolumn{1}{l}{ I }
\end{tabular} & II & III & TOTAL \\
\hline GREECE & $\mathbf{5 8 4 3}$ & $\mathbf{2 5 0 4 7}$ & $\mathbf{1 2 6 2 9 7}$ & $\mathbf{1 5 7 1 8 7}$ \\
ATTICA & 307 & 9155 & 66509 & $\mathbf{7 5 9 7 1}$ \\
NORTH AEGEAN & 110 & 233 & 1918 & $\mathbf{2 2 6 1}$ \\
SOUTH AEGEAN & 132 & 584 & 4578 & $\mathbf{5 2 9 4}$ \\
CRETE & 461 & 957 & 6261 & $\mathbf{7 6 7 9}$ \\
EASTERN & & & & \\
MACEDONIA, & $\mathbf{4 3 3}$ & $\mathbf{1 1 1 7}$ & $\mathbf{4 5 4 8}$ & $\mathbf{6 0 9 8}$ \\
THRACE & & & & \\
CENTRAL & 1163 & 3681 & 16120 & $\mathbf{2 0 9 6 4}$ \\
MACEDONIA & & & & \\
WESTERN & 238 & 1908 & 1685 & $\mathbf{3 8 3 1}$ \\
MACEDONIA & & 573 & 2633 & $\mathbf{3 4 8 7}$ \\
EPIRUS & 281 & 1514 & 5614 & $\mathbf{7 9 5 3}$ \\
THESSALY & 825 & 204 & 2417 & $\mathbf{2 7 1 6}$ \\
IONIAN ISLANDS & 95 & 1058 & 5570 & $\mathbf{7 2 8 8}$ \\
WESTERN GREECE & 660 & 2450 & 3850 & $\mathbf{6 8 6 6}$ \\
CENTRAL GREECE & 566 & 1613 & 4594 & $\mathbf{6 7 7 9}$ \\
PELOPONNESE & 572 & &
\end{tabular}

Source: Hellenic Statistical Authority - Calculated data. *Temporary data. Update 17/01/2017. 
Table 9. Location Quotient (LQ), Coefficient of Specialization (CS)

\begin{tabular}{lllll}
\hline \multicolumn{2}{l}{ By region and sector, 2014 (Based on Table 8) } & & \\
I= Primary, II= Secondary, III= Tertiary & & & \\
& LQ (I) & LQ (II) & LQ (III) & CS \\
\hline ATTICA & 0.10759 & 0.75623 & 1.08952 & 0.06 \\
NORTH AEGEAN & 1.25139 & 0.64676 & 1.07143 & 0.053 \\
SOUTH AEGEAN & 0.65321 & 0.69228 & 1.07601 & 0.058 \\
CRETE & 0.15966 & 0.7821 & 1.01476 & 0.031 \\
EASTERN & & & & \\
MACEDONIA, & $\mathbf{1 . 9 0 7 4 6}$ & $\mathbf{1 . 1 4 9 5 3}$ & $\mathbf{0 . 9 2 8 2 1}$ & $\mathbf{0 . 0 6}$ \\
THRACE & & & & \\
CENTRAL & 1.48841 & 1.10193 & 0.95701 & 0.037 \\
MACEDONIA & & 3.12559 & 0.54743 & 0.36 \\
WESTERN & 0.16414 & 1.03124 & 0.93978 & 0.05 \\
MACEDONIA & 2.16372 & 1.19468 & 0.87855 & 0.1 \\
EPIRUS & 2.78678 & 0.47138 & 1.10753 & 0.08 \\
THESSALY & 0.92598 & 0.91105 & 0.95119 & 0.047 \\
IONIAN ISLANDS & 2.41562 & 2.23938 & 0.69789 & 0.24 \\
WESTERN GREECE & 2.1978 & 1.48399 & 0.84344 & 0.12 \\
CENTRAL GREECE & 2.24917 & &
\end{tabular}

Source: Hellenic Statistical Authority - Calculated data. *Temporary data. Update 17/01/2017.

The literature of regional development indicates that, if $L Q>1$, the considered activity is standard and exporting; if $L Q<1$ then it is non-standard; and if $L Q=1$ it is a balanced activity. According to Table 9, the Eastern Macedonia and Thrace's primary and secondary productive sectors are standard or specialized in their productive activities while the tertiary is a non-standard. The specialization coefficient of the region (0.06) signalizes absence of specialization with regard to the distribution of the national activities; the country's industrial structure corresponds to the respective structure of the region. 
Table 10. Employment

\begin{tabular}{lllll}
\hline \multicolumn{2}{l}{ By region and sector, 2014* } & & & \\
I= Primary, II= Secondary, III= Tertiary & & & \\
& I & II & III & TOTAL \\
\hline GREECE & $\mathbf{4 8 8 4 1 3}$ & $\mathbf{5 7 9 4 7 3}$ & $\mathbf{2 9 3 1 4 1 0}$ & $\mathbf{3 9 9 9 2 9 6}$ \\
ATTICA & 13705 & 210338 & 1303370 & 1527413 \\
NORTH AEGEAN & 8546 & 7809 & 52288 & 68643 \\
SOUTH AEGEAN & 10460 & 19111 & 104041 & 133612 \\
CRETE & 41097 & 32908 & 163775 & 237780 \\
EASTERN & & & & \\
MACEDONIA, & $\mathbf{6 0 0 8 6}$ & $\mathbf{2 6 6 3 1}$ & $\mathbf{1 2 4 0 8 6}$ & $\mathbf{2 1 0 8 0 3}$ \\
THRACE & & & & \\
CENTRAL & 87749 & 94586 & 453511 & 635846 \\
MACEDONIA & 15693 & 21706 & 52446 & 89845 \\
WESTERN & 23081 & 17503 & 75983 & 116567 \\
MACEDONIA & 62642 & 40684 & 159428 & 262754 \\
EPIRUS & 12471 & 9608 & 59646 & 81725 \\
THESSALY & 50926 & 27927 & 148379 & 227232 \\
IONIAN ISLANDS & 39826 & 42907 & 111202 & 193935 \\
WESTERN GREECE & 62130 & 27754 & 123255 & 213139 \\
CENTRAL GREECE & & &
\end{tabular}

Source: Hellenic Statistical Authority - Calculated data. *Temporary data. Update 17/01/2017.

Table 11. Regional Multiplier \& Total Multiplier

\begin{tabular}{|c|c|c|c|c|}
\hline \multicolumn{5}{|c|}{$\begin{array}{l}\text { By region and sector, } 2014 \text { (Based on Table 10) } \\
\text { I= Primary, II= Secondary, III= Tertiary }\end{array}$} \\
\hline & I & II & III & TOTAL \\
\hline ATTICA & & & 7.09 & 8.31 \\
\hline NORTH AEGEAN & \multicolumn{2}{|l|}{52.32} & 26.5 & 32.13 \\
\hline SOUTH AEGEAN & & & 17 & 3.45 \\
\hline CRETE & 3.4 & & & 19.71 \\
\hline $\begin{array}{l}\text { EASTERN } \\
\text { MACEDONIA, } \\
\text { THRACE }\end{array}$ & 1.75 & & & 6.14 \\
\hline CENTRAL MACEDONIA & 79.8 & 38.6 & & 179 \\
\hline $\begin{array}{l}\text { WESTERN } \\
\text { MACEDONIA }\end{array}$ & 3.32 & 2.5 & & 6.7 \\
\hline EPIRUS & 2.6 & 28.6 & & 12.32 \\
\hline THESSALY & 2.05 & 15.58 & & 46.36 \\
\hline IONIAN ISLANDS & 5 & & & 32.81 \\
\hline WESTERN GREECE & 2.2 & & & 9.8 \\
\hline CENTRAL GREECE & 2.47 & 2.9 & & 6.26 \\
\hline PELOPONNESE & 1.72 & & & 5.9 \\
\hline
\end{tabular}




\section{Macrothink}

Regional multiplier:

$$
\operatorname{Kir}=\frac{A i r}{\left[\operatorname{Air}-\left(\frac{A i n}{A n}\right) A r\right]}
$$

Air $=$ Employment in sector $i$ and region $r$

$A r=$ Total employment in region $r$

Ain $=$ Employment of sector $i$ in country's total

$A n=$ Total country's employment

The calculated regional multiplier of the target-region in Table 11 (1.75) signifies a multiplying effect and exporting activity only in the primary sector (value greater than 1). The regional multiplier measures the region's total raise of employment by taking into account the increase in number of employed in exports. In other words, it weighs the influence of each export unit in the total activity of the region.

\subsection{Shift-Share Analysis}

Based on the Gross Value Added by industry (Table 7) we calculate the Shift-Share analysis' components (Barff and Knight, 1988) according to the following types (Table 12):

Table 12.

$\frac{A n t}{A n o}=\frac{3098}{4805}=0.644$

$\frac{\text { AAFFnt }}{\text { AFFno }}=\frac{433}{499}=0.86$

$\left(\frac{A A F F n t}{A F F n o}\right)-\left(\frac{A n t}{\text { Ano }}\right)=0.86-0.644=-0.223$

$\frac{\text { AMEGnt }}{\text { AMEGno }}=\frac{248}{298}=0.83$

$\left(\frac{A M E G n t}{A M E G n o}\right)-\left(\frac{A n t}{A n o}\right)=0.83-0.644=0.19$

$\frac{A M n t}{A M n o}=\frac{689}{947}=0.73$

$\left(\frac{A M n t}{A M n o}\right)-\left(\frac{A n t}{A n o}\right)=0.73-0.644=0.09$

$\frac{\text { Acnt }}{A C n o}=\frac{180}{439}=0.41$

$\left(\frac{A C n t}{A C n o}\right)-\left(\frac{A n t}{A n o}\right)=0.41-0.644=-0.23$

$\frac{\text { ATTAFSnt }}{\text { ATTAFSno }}=\frac{1261}{2094}=0.6$

\section{National Growth Effect}

$\mathrm{E} \Sigma r=\operatorname{Aro}\left(\frac{A n t}{A n o}\right)-$ Aro

Industrial Mix Effect

$O \Sigma r=\sum\left[\left\{\left(\frac{A \text { int }}{\text { Aino }}\right)-\left(\frac{\text { Ant }}{\text { Ano }}\right)\right\}\right.$ Airo $]$

Local Share Effect

$\Delta \Sigma r=\sum\left[\right.$ Airt - Airo $\left.\left(\frac{\text { Aint }}{\text { Aino }}\right)\right]$

Actual Growth

$M r=E r+O r+\Delta r$ 
$\frac{\text { AFIAnt }}{\text { AFIAno }}=0.79 \quad\left(\frac{\text { AFIAnt }}{\text { AFIAno }}\right)-\left(\frac{\text { Ant }}{\text { Ano }}\right)=0.79-0.644=0.15$

$\frac{\text { APSTAnt }}{\text { APSTAno }}=0.39 \quad\left(\frac{\text { APSTAnt }}{\text { APSTAno }}\right)-\left(\frac{\text { Ant }}{\text { Ano }}\right)=0.39-0.644=-0.25$

5.1.1 The shift and share variables of Eastern Macedonia and Thrace's prefectures by industry Table 13. AFF: Agriculture-Forestry-Fishing

\begin{tabular}{lllll}
\hline & $\begin{array}{l}\text { NATIONAL GROWTH } \\
\text { EFFECT }\end{array}$ & $\begin{array}{l}\text { INDUSTRIAL MIX } \\
\text { EFFECT }\end{array}$ & $\begin{array}{l}\text { LOCAL SHARE } \\
\text { FFECT }\end{array}$ & $\begin{array}{l}\text { ACTUAL } \\
\text { GROWTH }\end{array}$ \\
\hline EVROS & $121 * 0.644-121=-43.08$ & $0.223 * 121=26.98$ & $103-121 * 0.5=42.5$ & 18 \\
XANTHI & $79 * 0.644-79=28.12$ & $0.223 * 79=17.61$ & $69-70 * 0.5=34$ & -5.49 \\
RODOPE & $91 * 0.644-121=-62.4$ & $0.223 * 91=20.3$ & $85-91 * 0.5=39.5$ & -36 \\
DRAMA & $98 * 0.644-98=-34.9$ & $0.223 * 98=21.85$ & $87-98 * 0.5=38$ & -11.01 \\
KAVALA & $110 * 0.644-110=-39.16$ & $0.223 * 110=24.53$ & $89-110 * 0.5=34$ & -21 \\
SUM & $\mathbf{- 2 0 7 . 6 6}$ & $-\mathbf{1 1 1 . 2 7}$ & $\mathbf{1 8 8}$ & $\mathbf{- 9 1 . 5}$ \\
\hline
\end{tabular}

With regard to the AFF industry, Table 13 indicates that all prefectures of Eastern Macedonia and Thrace, in terms of Boudeville regional classification (Boudeville, 1966), are of "regional type 4", since $O r<0, \Delta r>0$ and $|O r|<|\Delta r|$ (according to the regional analysis literature, in the inequality between $O r$ and $\Delta r$ their absolute value is taken into account). Obviously the region in total is classified as "type 2 " for the AFF industry.

This translates into a favorable industrial structure (concentration to low growth rate industrial activities, compared to nation's averages) whereas, regarding the AFF industry, positive local effects take place. Thus, the proposed measure is an industrial structure improvement.

Table 14. MEG: Mining-Electricity-Gas

\begin{tabular}{llllll}
\hline & $\begin{array}{l}\text { NATIONAL } \\
\text { GROWTH } \\
\text { EFFECT }\end{array}$ & $\begin{array}{l}\text { INDUSTRIAL } \\
\text { EFFECT }\end{array}$ & $\begin{array}{l}\text { MIX } \\
\text { LOCAL } \\
\text { EFFEC }\end{array}$ & SHARE & $\begin{array}{l}\text { ACTUAL } \\
\text { GROWTH }\end{array}$ \\
\hline EVROS & -13.9 & 7.41 & 5.63 & $\mathbf{- 0 . 8 6}$ \\
XANTHI & -11.4 & 6.08 & -8.56 & $\mathbf{- 1 3 . 8 8}$ \\
RODOPE & -36.31 & 19.38 & -30.66 & $\mathbf{- 4 7 . 5 9}$ \\
DRAMA & -18.56 & 9.69 & 21.67 & $\mathbf{1 2 . 8}$ \\
KAVALA & -26.34 & 14.06 & 12.58 & $\mathbf{0 . 3}$ \\
SUM & $-\mathbf{1 0 6 . 5 1}$ & $\mathbf{5 6 . 6 2}$ & $\mathbf{0 . 6 6}$ & $\mathbf{- 4 9 . 2 3}$ \\
\hline
\end{tabular}


With regard to the MEG industry (Table 14), for the prefectures and region:

A. Evros: $O r>0, \Delta r>0$ and $|O r|>|\Delta r|$, therefore "regional type 1", according to which there is a favorable industrial structure with positive local effects.

B. Xanthi: $O r>0, \Delta r<0$ and $|\boldsymbol{O r}|<|\Delta \boldsymbol{r}|$, therefore "regional type 6", according to which there is a favorable industrial structure with positive local effects. The proposed measure is infrastructure improvement.

C. Rodope: $O r>0, \Delta r<0$ and $|\boldsymbol{O r}|<|\Delta \boldsymbol{r}|$, therefore "regional type 6", according to which there is a favorable industrial structure with negative local effects. The proposed measure is infrastructure improvement.

D. Drama and Kavala are of "regional types 1 and 2" respectively, therefore favorable industrial structure and positive local effects.

E. The region in total is of "regional type 1": $O r>0, \Delta r>0$ and $|O r|>|\Delta r|$, therefore favorable industrial structure and positive local effects.

Table 15. M: Manufacturing

\begin{tabular}{lllll}
\hline & $\begin{array}{l}\text { NATIONAL } \\
\text { GROWTH } \\
\text { EFFECT }\end{array}$ & $\begin{array}{l}\text { INDUSTRIAL } \\
\text { MIX EFFECT }\end{array}$ & $\begin{array}{l}\text { LOCAL } \\
\text { EFFECT }\end{array}$ & $\begin{array}{l}\text { SHARE } \\
\text { ACTUAL } \\
\text { GROWTH }\end{array}$ \\
\hline EVROS & -51.62 & 13.05 & 8.15 & $\mathbf{- 3 0 . 4 2}$ \\
XANTHI & -69.42 & 17.55 & 16.35 & $\mathbf{- 3 5 . 5 2}$ \\
RODOPE & -67.64 & 17.1 & -21.7 & $\mathbf{- 7 2 . 2 4}$ \\
DRAMA & -59.45 & 15.03 & -1.91 & $\mathbf{- 4 6 . 3 3}$ \\
KAVALA & -89 & 22.5 & 29.5 & $\mathbf{- 3 7}$ \\
SUM & $-\mathbf{3 3 7 . 1 3}$ & $\mathbf{8 5 . 2 3}$ & $\mathbf{3 0 . 3 9}$ & $\mathbf{- 2 2 1 . 5 1}$ \\
\hline
\end{tabular}

With regard to the M industry (Table 15), for the prefectures and region:

A. Evros: $O r>0, \Delta r>0$ and $|O r|>|\Delta r|$, therefore "regional type 1", according to which there is a favorable industrial structure with positive local effects.

B. Xanthi and Drama: $O r>0, \Delta r<0$ and $|\boldsymbol{O r}|>|\Delta \boldsymbol{r}|$, therefore "regional type 3", according to which there is favorable industrial structure but negative local effects. The proposed measure is infrastructure improvement.

C. Rodope: $O r>0, \Delta r<0$ and $|\boldsymbol{O r}|<|\Delta \boldsymbol{r}|$, therefore "regional type 6", according to which there is a favorable industrial structure but negative local effects. The proposed measure is infrastructure improvement. 
D. Kavala: $O r>0, \Delta r>0$ and $|O r<\Delta r|$, therefore "regional type 2". Favorable industrial structure and positive local effects.

E. The region in total is of "regional type 1": $O r>0, \Delta r>0$ and $|O r|>|\Delta r|$, therefore favorable industrial structure and positive local effects.

Table 16. C: Construction

\begin{tabular}{lllll}
\hline & $\begin{array}{l}\text { NATIONAL } \\
\text { GROWTH } \\
\text { EFFECT }\end{array}$ & $\begin{array}{l}\text { INDUSTRIAL } \\
\text { MIX EFFECT }\end{array}$ & $\begin{array}{l}\text { LOCAL } \\
\text { EFFECT }\end{array}$ & $\begin{array}{l}\text { SHARE } \\
\text { ACTUAL } \\
\text { GROWTH }\end{array}$ \\
\hline EVROS & -30.61 & -17.2 & -18.26 & $\mathbf{- 6 6 . 0 7}$ \\
XANTHI & -34.18 & -19.2 & -11.36 & $\mathbf{- 6 4 . 7 4}$ \\
RODOPE & -27.77 & -17.94 & -12.98 & $\mathbf{- 5 8 . 6 9}$ \\
DRAMA & -15.67 & -10.12 & 25.2 & $\mathbf{- 0 . 5 9}$ \\
KAVALA & -47.7 & -30.82 & 16.06 & $\mathbf{- 6 2 . 4 6}$ \\
SUM & $-\mathbf{1 5 5 . 9 3}$ & $\mathbf{- 9 5 . 2 8}$ & $-\mathbf{1 . 3 4}$ & $\mathbf{- 2 5 2 . 5 5}$ \\
\hline
\end{tabular}

With regard to the $\mathrm{C}$ industry (Table 16 ), for the prefectures and region:

A. Evros: $O r<0, \Delta r<0$ and $|\boldsymbol{O r}|<|\Delta \boldsymbol{r}|$, therefore "regional type 8", according to which there is an unfavorable industrial structure and negative local effects. The proposed strategic measure is an industrial structure improvement.

B. Xanthi and Rodope: $O r<0, \Delta r<0$ and $|\boldsymbol{O r}|>|\Delta \boldsymbol{r}|$, therefore "regional type 7", according to which there is an unfavorable industrial structure and negative local effects. The proposed strategic measure is infrastructure improvement.

C. Drama: $O r<0, \Delta r>0$ and $|O r|<|\Delta r|$, therefore "regional type 4". Positive local effects but unfavorable industrial structure. The proposed measure is an industrial structure improvement.

D. Kavala: $O r<0, \Delta r>0$ and $|\boldsymbol{O r}|>|\Delta \boldsymbol{r}|$, therefore "regional type 5", according to which there is an unfavorable industrial structure but positive local effects. The proposed measure is an industrial structure improvement.

E. The region in total is of "regional type 7": Or<0, $\Delta r<0$ and $|\boldsymbol{O r}|>|\Delta \boldsymbol{r}|$, therefore unfavorable industrial structure and negative local effects. The proposed strategic measure is infrastructure improvement. 
Table 17. TTAFS: Trade-Transportation-Accommodation-Food Services

\begin{tabular}{|c|c|c|c|c|}
\hline & $\begin{array}{l}\text { NATIONAL } \\
\text { GROWTH } \\
\text { EFFECT }\end{array}$ & $\begin{array}{l}\text { INDUSTRIAL } \\
\text { MIX EFFECT }\end{array}$ & $\begin{array}{l}\text { LOCAL SHARE } \\
\text { EFFECT }\end{array}$ & $\begin{array}{l}\text { ACTUAL } \\
\text { GROWTH }\end{array}$ \\
\hline EVROS & -164.5 & -18.48 & -32.2 & -215.18 \\
\hline XANTHI & -87.6 & -9.84 & 15.4 & -82.04 \\
\hline RODOPE & -91.85 & -10.32 & 2.2 & -99.97 \\
\hline DRAMA & -91.14 & -10.24 & 1.4 & -99.98 \\
\hline KAVALA & -310.43 & -34.88 & 18.8 & -326.51 \\
\hline SUM & -745.52 & -83.76 & 5.6 & -823.68 \\
\hline
\end{tabular}

With regard to the TTAFS industry (Table 17), for the prefectures and region:

A. Evros: $O r<0, \Delta r<0$ and $|\boldsymbol{O r}|<|\Delta \boldsymbol{r}|$, therefore "regional type 8", according to which there are negative local effects and unfavorable industrial structure. The proposed measure is an industrial structure improvement.

B. Xanthi: $O r<0, \Delta r>0$ and $|\boldsymbol{O r}|<|\Delta \boldsymbol{r}|$, therefore "regional type 4", according to which there are positive local effects but unfavorable industrial structure. The proposed strategic measure is an industrial structure improvement.

C. Rodope, Drama and Kavala: Or<0, $\Delta r>0$ and $|\boldsymbol{O r}|>|\Delta \boldsymbol{r}|$, therefore "regional type 5". Positive local effects take place but unfavorable industrial structure. The proposed strategic measure is an industrial structure improvement.

D. The region in total is of "regional type 5": $O r<0, \Delta r>0$ and $|\boldsymbol{O r}|>|\Delta \boldsymbol{r}|$. There are positive local effects but unfavorable industrial structure. The proposed strategic measure is an industrial structure improvement.

Table 18. FIA: Financial and Insurance Activities

\begin{tabular}{|c|c|c|c|c|}
\hline & $\begin{array}{l}\text { NATIONAL } \\
\text { GROWTH } \\
\text { EFFECT }\end{array}$ & $\begin{array}{l}\text { INDUSTRIAL } \\
\text { MIX EFFECT }\end{array}$ & $\begin{array}{l}\text { LOCAL SHARE } \\
\text { EFFECT }\end{array}$ & $\begin{array}{l}\text { ACTUAL } \\
\text { GROWTH }\end{array}$ \\
\hline EVROS & -16.73 & 7.05 & 1.87 & -7.81 \\
\hline XANTHI & -11.03 & 4.65 & 0.51 & -5.87 \\
\hline RODOPE & -12.46 & 5.25 & -5.65 & -12.86 \\
\hline DRAMA & -11.75 & 4.95 & 3.93 & -2.87 \\
\hline KAVALA & -21 & 8.85 & 0.39 & -11.76 \\
\hline SUM & -72.97 & 30.75 & 1.05 & -41.17 \\
\hline
\end{tabular}

With regard to the FIA industry (Table 18), for the prefectures and region: 
A. Evros, Xanthi, Drama and Kavala: $O r>0, \Delta r>0$ and $|O r|>|\Delta r|$, therefore "regional type 1", which is a favorable industrial structure with positive local effects.

B. Rodope: $O r>0, \Delta r<0$ and $|\boldsymbol{O r}|<|\Delta \boldsymbol{r}|$, therefore "regional type 6", which implies favorable industrial structure but negative local effects. The proposed measure is an industrial structure improvement.

C. The region in total is of "regional type 1": $O r>0, \Delta r>0$ and $|O r|>|\Delta r|$, therefore favorable industrial structure and positive local effects.

Table 19. PSTA: Professional, Scientific and Technical Activities

\begin{tabular}{|c|c|c|c|c|}
\hline & $\begin{array}{l}\text { NATIONAL } \\
\text { GROWTH } \\
\text { EFFECT }\end{array}$ & $\begin{array}{l}\text { INDUSTRIAL } \\
\text { MIX EFFECT }\end{array}$ & $\begin{array}{l}\text { LOCAL SHARE } \\
\text { EFFECT }\end{array}$ & $\begin{array}{l}\text { ACTUAL } \\
\text { GROWTH }\end{array}$ \\
\hline EVROS & -18.52 & -13 & 5.72 & -25.8 \\
\hline XANTHI & -25.63 & -18 & 4.72 & -38.91 \\
\hline RODOPE & -24.56 & -17.25 & -4.91 & -46.72 \\
\hline DRAMA & -23.5 & -16.5 & -14.74 & -54.74 \\
\hline KAVALA & -22.8 & -16 & 16.04 & -22.76 \\
\hline SUM & -115.01 & -80.75 & 6.83 & -188.93 \\
\hline
\end{tabular}

With regard to the PSTA industry (Table 19), for the prefectures and region:

A. Evros and Xanthi: $O r<0, \Delta r>0$ and $|\boldsymbol{O r}|>|\Delta \boldsymbol{r}|$, therefore "regional type 5". That is positive local effects but unfavorable industrial structure. The proposed measure is an industrial structure improvement

B. Rodope: $O r<0, \Delta r<0$ and $|\boldsymbol{O r}|>|\Delta \boldsymbol{r}|$, therefore "regional type 7", which is negative local effects and unfavorable industrial structure. This implies strategic measures at infrastructure improvement.

C. Drama: $O r<0, \Delta r<0$ and $|\boldsymbol{O r}|<|\Delta \boldsymbol{r}|$, therefore "regional type 8", according to which there are negative local effects and unfavorable industrial structure. The proposed measure is an industrial structure improvement.

D. Kavala: $O r<0, \Delta r>0$ and $|\boldsymbol{O r}|<|\Delta r|$, therefore "regional type 4", which implies positive local effects but unfavorable industrial structure. The proposed strategic measure is an industrial structure improvement.

E. The region in total is of "regional type 5": $O r<0, \Delta r>0$ and $|\mathrm{Or}|>|\Delta \boldsymbol{r}|$, which implies positive local effects but unfavorable industrial structure. The proposed strategic measure is an industrial structure improvement. 


\section{Conclusion}

In conclusion, the analysis of our data leads to a specialized proposal for the creation of the first LDI, as a mechanism for strengthening the local business ecosystems, in the Eastern Macedonia and Thrace region. The logic behind this is to provide a privileged developmental "cure" to the weakest localities of Greece today.

This target-region we picked appears to fit in the qualitative and quantitative criteria, compared to the rest of the Greek regions, and, therefore, the proposed policy approach could be prioritized in this particular area.

\section{References}

\section{In English}

Ács, Z. J., Szerb, L., Autio, E., \& Lloyd, A. (2017). The Global Entrepreneurship Index 2017. Washington, D.C: Global Entrepreneurship Development Institute. https://doi.org/10.1007/978-3-319-65903-9_3

Anggraeni, E., Den Hartigh, E., \& Zegveld, M. (2007). Business ecosystem as a perspective for studying the relations between firms and their business networks. ECCON 2007.

Barff, R. A., \& Knight, P. L. (1988). Dynamic Shift-Share Analysis. A Journal of Urban and Regional Policy, 19(2), 1-10. https://doi.org/10.1111/j.1468-2257.1988.tb00465.x

Blakely, E. (1989). Planning Local Economic Development. SAGE.

Boudeville, J. (1966). Problems of Economic Regional Planning. Edinburg University Press.

Chang, V., \& Uden, L. (2008). Governance for E-learning ecosystem. (IEEE, Ed.) Digital Ecosystems and Technologies, 2008. DEST 2008. 2nd IEEE International Conference on. https://doi.org/10.1109/DEST.2008.4635164

Desai, N., Mazzoleni, P., \& Tai, S. (2007). Service Communities: A Structuring Mechanism for Service-Oriented Business Ecosystems. Digital EcoSystems and Technologies Conference, 2007. DEST '07. Inaugural IEEE-IES. https://doi.org/10.1109/DEST.2007.371957

Eurostat. (2011). Key figures on European business with a special feature on SMEs. European union. Luxembourg: Publications Office of the European Union.

Fragidis, G., Koumpis, A., \& Tarabanis, K. (2007). The Impact of Customer Participation on Business Ecosystems. In L. M. Camarinha-Matos, H. Afsarmanesh, P. Novais, \& C. Analide, Establishing the Foundation of Collaborative Networks. IFIP - The International Federation for Information Processing (Vol. 243, pp. 399-406). Springer, Boston, MA. https://doi.org/10.1007/978-0-387-73798-0_42

Iansiti, M., \& Levien, R. (2004). Strategy as Ecology. Harvard Business Review, 68-81.

Li, Y. R. (2009). The technological roadmap of Cisco's business ecosystem. Technovation, 29(5), 379-386. https://doi.org/10.1016/j.technovation.2009.01.007 
Marín, C. A., Stalker, I., \& Mehandjiev, N. (2007). Business Ecosystem Modelling: Combining Natural Ecosystems and Multi-Agent Systems. In M. Klusch, K. V. Hindriks, M. P. Papazoglou, \& L. Sterling, Cooperative Information Agents XI. CIA 2007. Lecture Notes in Computer Science (Vol. 4676, pp. 181-195). Springer, Berlin, Heidelberg. https://doi.org/10.1007/978-3-540-75119-9_13

Moore, J. F. (1993). Predators and prey: A new ecology of competition. Harvard Business Review, 71(3), 75-86.

Moore, J. F. (1996). The death of competition: leadership and strategy in the age of business ecosystems. New York: Harper Business.

Moore, J. F. (2014). Shared Purpose: A thousand business ecosystems, a connected community, and the future (3rd ed.). First Ecosystem.

Peltoniemi, M. (2005). Business Ecosystem: A conceptual model of an organisation population from the perspectives of complexity and evolution. e-Business Research Center, Research Reports 18.

Peltoniemi, M., \& Vuori, E. (2004). Business ecosystem as the new approach to complex adaptive business environments. Proceedings of eBusiness Research Forum, 18, 267-281.

Rong, K., \& Shi, Y. (2015). Business Ecosystems: Constructs, Configurations, and the Nurturing Process. Palgrave Macmillan UK. https://doi.org/10.1057/9781137405920

Schwab, K., Sala i Martin, X., \& World Economic Forum. (2016). The Global Competitiveness Report 2016-2017. World Economic Forum.

Tansley, A. (1935, July). The Use and Abuse of Vegetational Concepts and Terms. Ecology, 16(3), 284-307. https://doi.org/10.2307/1930070

Vlados, Ch. (1996). International restructuring dynamics of competitive advantage. Middle East Forum, 1, 233-252.

Vlados, Ch. (2005, October). The Insertion of Greek Firms into Globalization: The Dynamics of the Triangle of Strategy, Technology and Management. Tome of proceedings of International Conference: "Managing Global Trends and Challenges in a Turbulent Economy”. University of the Aegean, Department of Business Administration.

Vlados, Ch. (2012). The Search of Competitiveness and the Entrepreneurial Evolution in a Global Environment: Toward a new approach of Development Dynamics based on the case of Greek Productive System. Journal of Management Sciences and Regional Development. Issue 8, January 2012.

Vlados, Ch., Katimertzopoulos, F. (2017). Local Support Mechanisms for Entrepreneurship: The Approach of Local Development and Innovation Institutions. International Journal of Business and Economic Sciences Applied Research, 10(1). 


\section{Macrothink}

International Journal of Regional Development ISSN 2373-9851 2018, Vol. 5, No. 1

Williamson, P. J., \& De Meyer, A. (2012). Ecosystem Advantage: How to Successfully Harness the Power of Partners. California management review, 55(1), 24-46. https://doi.org/10.1525/cmr.2012.55.1.24

\section{In Greek}

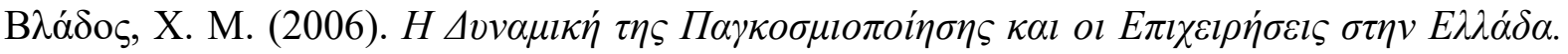

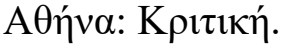

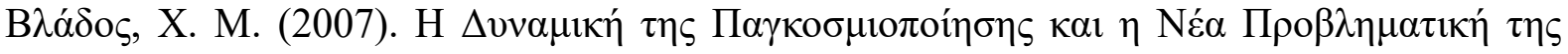

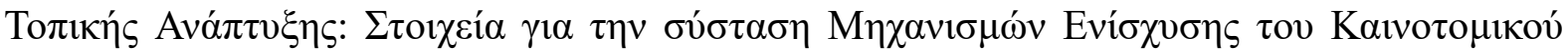

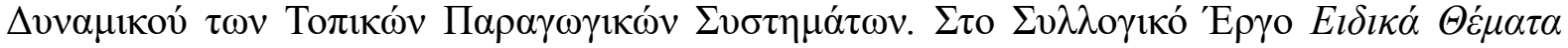

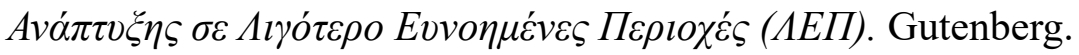

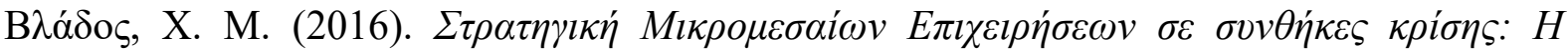

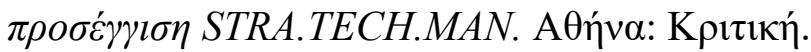

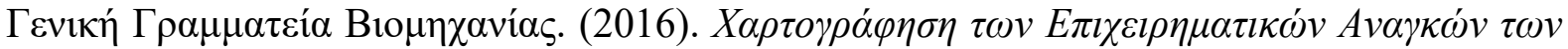

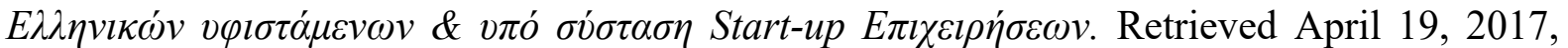
from http://startupgreece.gov.gr/sites/default/files/hartografisi_anagkon_20.12.2016_0.pdf

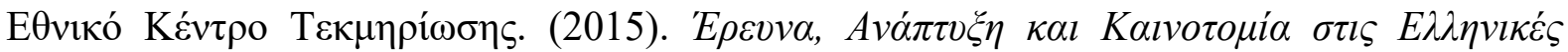

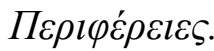

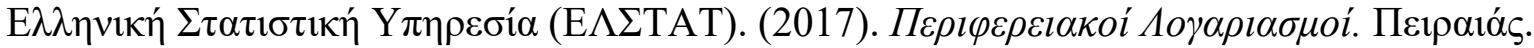

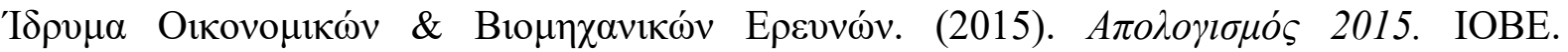
Retrieved April 19, 2017, from http://iobe.gr/docs/IOBE_Report_2015.pdf

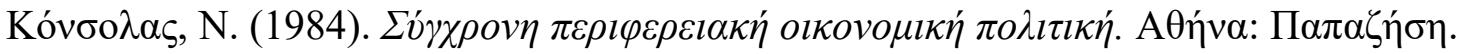

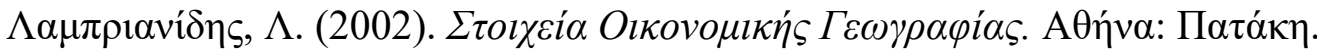

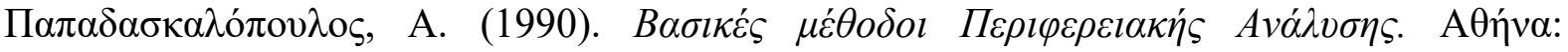

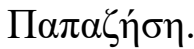

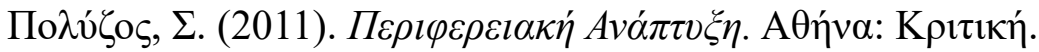

Note

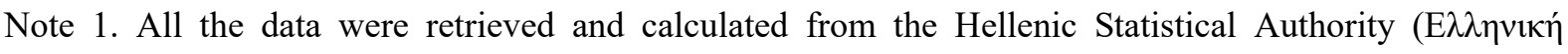

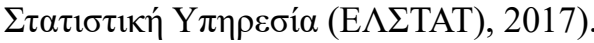

\section{Copyright Disclaimer}

Copyright for this article is retained by the author(s), with first publication rights granted to the journal.

This is an open-access article distributed under the terms and conditions of the Creative Commons Attribution license (http://creativecommons.org/licenses/by/3.0/). 